\title{
A EXECUÇÃO PROVISÓRIA DA PENA E SUA COMPATIBILIDADE COM A PRESUNÇÃO DE INOCÊNCIA COMO DECORRÊNCIA DO SISTEMA ACUSATÓRIO
}

\author{
PROVISIONAL EXECUTION OF CRIMINAL SENTENCE AND ITS CONFORMITY TO \\ THE PRESUMPTION OF INNOCENCE AS A CONSEQUENCE OF THE ACCUSATORY \\ SYSTEM
}

\begin{abstract}
Antonio Henrique Graciano Suxberger
Doutor em "Derechos Humanos y Desarrollo" pela Universidad Pablo de Olavide. Atualmente é Professor do Programa de Mestrado e Doutorado em Direito do Centro

Universitário de Brasília (UniCEUB) e dos cursos de pós-graduação lato sensu da

Fundação Escola Superior do MPDFT (FESMPDFT). É professor do máster oficial universitário em Direitos Humanos, Interculturalidade e Desenvolvimento da Universidade Pablo de Olavide e Professor Investigador do Programa de Doutorado em

Ciências Jurídicas e Políticas da mesma Universidade (linha: Direitos Humanos e Desenvolvimento). É Promotor de Justiça do Ministério Público do Distrito Federal e Territórios. E-mail: antonio.suxberger@uniceub.br
\end{abstract}

Marianne Gomes de Amaral

Bacharel em Direito. Especialista em "Ordem Jurídica e Ministério Público" pela Fundação Escola Superior do MPDFT. Servidora do Tribunal de Justiça do Distrito Federal e Territórios. E-mail: mariannegamaral@gmail.com

Recebido em: 13/10/2016

Aprovado em: 10/01/2017

Doi: $10.5585 /$ rdb.v16i7.500

RESUMO: O artigo objetiva examinar a execução provisória da pena e sua compatibilidade com o princípio da presunção de inocência a partir da compreensão dada ao tema no Brasil pelo Supremo Tribunal Federal (STF). Valendo-se de análise documental, especialmente as decisões proferidas pelo Supremo Tribunal Federal, e revisão bibliográfica, o artigo cuida das decisões proferidas no Habeas Corpus 84.078 em 2009 e no Habeas Corpus 126.292 em 2016. Pretende demonstrar que a execução provisória da pena privativa de liberdade, após a condenação em segundo grau, não viola o núcleo da presunção de inocência tal como positivada na Constituição da República e nas Convenções de Direitos Humanos de que o Brasil é signatário. Além disso, indica que a execução provisória da pena atua como decorrência do processo penal acusatório, com preocupação dirigida às cláusulas do devido processo legal. Intenta demonstrar que a orientação do Supremo Tribunal Federal assumida no ano de 2016 promove aprimoramento do Direito Processual Penal brasileiro e sua observância no sistema de justiça criminal. A metodologia adotada incluiu a análise documental dos julgados mencionados do STF e a revisão bibliográfica dos principais trabalhos sobre o tema.

Palavras-chave: Execução provisória da pena. Presunção de inocência. Sistema acusatório. Efetividade do sistema de justiça criminal. 
ABSTRACT: This article intends to examine the compatibility between the provisional execution of a criminal sentence and its conformity to the presumption of innocence regarding the Brazilian's Supreme Court view. According to documental analysis, specifically the opinions relating to the Habeas Corpus 84.078 in 2009 and the Habeas Corpus 126.292 in 2016, and bibliographical revision, the paper assays that the enforcement of a criminal sentence, after the decision provided by ordinary Courts, does not defy the core of the presumption of innocence as it is stablished in the Constitution and International Declarations mandatories to Brazil. Besides that, the provisional execution of a criminal sentence constitutes a foregone conclusion of the accusatory system and the clause of due process. The article affirms that the recent opinion of Supreme Court in 2016 brings into line the Criminal Procedural Law and improves the criminal justice system.

Keywords: Provisional execution of criminal sentence. Presumption of innocence. Accusatory system. Effectiveness of the criminal justice system.

SUMÁRIO: Introdução. 1. O sentido e o alcance da presunção de inocência. 2. A execução provisória da pena. 3. As decisões do STF. Conclusões. Referências.

\section{INTRODUÇÃO}

A tutela da presunção de inocência é essencial em um Estado Democrático de Direito e a própria lógica do sistema acusatório se baseia nessa garantia.

A definição do momento em que se inicia a execução da pena imposta por sentença condenatória no Brasil tem sido tema tormentoso especialmente após a Constituição de 1988. A Constituição brasileira, ao positivar a garantia da presunção de inocência, valeu-se de fórmula que, além de não expressar textual e claramente a presunção a que se referia, vinculou sua esgotabilidade ao trânsito em julgado da sentença penal condenatória.

De fato, a Constituição afirma que "ninguém será considerado culpado", em lugar de afirmar claramente a presunção de inocência. O uso dessa locução, em certa medida, problematizou a adoção no Brasil do postulado. Ainda assim, a pretensão de neutralidade do texto brasileiro não afastou a certeza de que, sim, o princípio da presunção de inocência foi positivado constitucionalmente pelo direito interno. Além disso, a Constituição menciona "até o trânsito em julgado de sentença penal condenatória", de modo a conduzir ao texto constitucional um conceito jurídico que é definido pela legislação infraconstitucional: o trânsito em julgado de sentença.

O distanciamento do texto constitucional em face da consagrada fórmula presente em convenções internacionais somado ao desenho do Código de Processo Penal, que trabalha com uma lógica segundo a qual a recorribilidade extraordinária não impede a efetividade da sentença condenatória, conduziram a uma série de debates que, apesar da manifestação derradeira do Supremo Tribunal Federal (STF) sobre o tema, permaneceram ativos ao longo dos anos.

A presença de argumentos, de um lado, que privilegiam de modo quase absoluto a inviabilidade de imposição da reprimenda estabelecida em sentença condenatória ainda não definitiva e, de outro lado, a organicidade e compreensão sistemática do funcionamento do sistema de justiça criminal, com ênfase no sistema recursal, permite a assertiva de que a execução provisória da pena é tema que interessa não só aos estudiosos do Direito Processual Penal mas também a todos os interessados no debate a respeito do eficientismo penal em contraposição a uma intervenção penal de cariz garantista.

Assim, analisar se a execução provisória da pena configura uma afronta à presunção de inocência, por si só, é um tema de bastante relevo. A orientação jurisprudencial, especialmente 
aquela estabelecida pelo Supremo Tribunal Federal, passou por um giro de cento e oitenta graus em 17/02/2016, no julgamento, pelo plenário da Corte, do HC 126.292. Após sete anos do julgamento do HC 84.078, paradigmático em relação ao tema, o STF restaurou a orientação tradicional da Corte no sentido de que a execução provisória de acórdão penal condenatório proferido em grau de apelação, ainda que sujeito a recurso especial ou extraordinário, não compromete o princípio constitucional da presunção de inocência.

Trata-se de orientação que impacta de forma bastante significativa na estrutura do sistema punitivo brasileiro e que inverte, diametralmente, a direção que vinha sendo seguida pelos Tribunais Superiores, razão pela qual se justifica a presente tentativa de análise do tema.

Esclareça-se, desde já, que não é pretensão do artigo o esgotamento da discussão, especialmente diante da riqueza de possibilidades e vieses em que se pode examiná-la. O objetivo do presente trabalho é examinar a compatibilidade entre a execução provisória da pena e o núcleo da presunção de inocência, bem como, diante de sua importância na fixação de uma orientação jurisprudencial, realizar uma análise quanto às decisões proferidas pelo STF no julgamento do HC 84.078 (2009) e do HC 126.292 (2016).

$\mathrm{Na}$ primeira parte do artigo, se buscará definir qual é o núcleo da presunção de inocência, estabelecendo o seu sentido e alcance, tendo como base para tanto a redação de tratados internacionais de que o Brasil é signatário. Na segunda parte do trabalho, serão examinadas as nuances que envolvem o início do cumprimento da pena após a fixação da responsabilidade penal em segundo grau, fazendo o cotejo entre a execução provisória, a presunção de inocência e o modelo acusatório de processo penal. Na terceira e última parte, serão examinadas as decisões proferidas pelo STF no julgamento do HC 84.078 (2009) e do HC 126.292 (2016). Particularmente quanto a este último, será feita breve análise dos votos dos Ministros Zavascki, Fachin e Barroso (favoráveis à retomada da orientação tradicional) e do Ministro Celso de Mello (contrário à alteração proposta). O trabalho ainda trará menção aos julgados de outubro de 2016, em sede de controle abstrato de constitucionalidade, quando o Pleno do STF, uma vez mais, confirmou seu entendimento sobre a compatibilidade da execução provisória da pena com a presunção de inocência fixada constitucionalmente.

A metodologia utilizada foi a análise documental, especificamente das decisões prolatadas pelo Supremo Tribunal Federal nos julgamentos mencionados acima, assim como a revisão bibliográfica de obras que cuidam do tema.

\section{O SENTIDO E O ALCANCE DA PRESUNÇÃO DE INOCÊNCIA}

A compreensão do sentido e do alcance de princípios jurídicos se relaciona diretamente com o contexto histórico em que estão sendo interpretados ${ }^{1}$, bem assim com o funcionamento do ordenamento jurídico em que se inserem. ${ }^{2}$ Dentro de uma lógica sistemática, em que se busca um funcionamento operacional, pautar a interpretação de um princípio apenas na literalidade do texto em que prescrito reduz a efetividade do sistema como um todo e acaba por negar concretização a outros princípios igualmente importantes à ordem constitucional.

\footnotetext{
${ }^{1}$ Essa ideia encontra apoio na doutrina de Mendes, Coelho e Branco (2008, p. 242), especialmente no destaque de que os direitos fundamentais possuem como característica o que se pode denominar de "historicidade". Assim, a depender das mazelas e conquistas de uma sociedade, em determinado período, os direitos fundamentais gozarão de um alcance maior ou menor, ou até nenhum alcance.

2 Não pode escapar a consideração de que a interpretação varia de acordo com interesses políticos, sendo extremamente influenciada, ainda, por posturas corporativistas. Necessário fazer essa observação, tendo em vista que, no cenário jurídico brasileiro, grande parte dos textos que discutem o tema que ora se pretende analisar variam sua conclusão de acordo com a profissão de seu redator, com bem analisado por Paulo César Busato (2016).
}

Revista de Direito Brasileira | São Paulo, SP | v. 16 | n. 7 | p. 186 - 210 | Jan./Abr. 2017 
Nesse contexto, é importante ressaltar que, no Brasil, a Constituição Federal propõe um Estado (Social) Democrático de Direito $^{3}$ e que o processo penal é orientado por um sistema acusatório.

Segundo a lição de Luigi Ferrajoli (2006, p. 519), o sistema processual acusatório é o que tem o juiz como um sujeito passivo rigidamente separado das partes e o julgamento marcado por um debate paritário, iniciado pela acusação, a quem compete o ônus da prova, desenvolvido pela defesa mediante contraditório público e oral, e culminado pela solução judicial, construída com base na livre convicção do julgador. Dessa conjuntura decorre uma sistemática principiológica pautada naquilo que se pode resumir, com apoio na doutrina de Ferrajoli, em um sistema penal garantista.

A esse respeito, Pacelli (2013, p. 25) afirma que a Constituição Federal de 1988 não deixa dúvidas quanto à sua opção garantista, pois consagra uma estrutura dialética do processo judicial, com a afirmação do contraditório, da ampla defesa, do juiz natural e do princípio da presunção da não culpabilidade. Complementa o autor: "Não se questiona, portanto, ao menos no âmbito do Processo Penal, a primazia da leitura garantista, abarcando, inclusive, todos os axiomas ${ }^{4}$ referidos por Ferrajoli" (PACELLI, 2013, p. 25).

Entretanto, o garantismo penal não pode (ou, ao menos, não deveria) ser compreendido de maneira parcial ou incompleta, com a adoção de um "garantismo hiperbólico monocular", em que se defende a qualquer custo a tutela exclusiva dos direitos individuais estabelecidos na Constituição em detrimento da proteção de direitos coletivos e deveres fundamentais, igualmente amparados pela ordem constitucional. Tal enfoque limitado de aplicação da teoria garantista rompe com a lógica do ordenamento e provoca uma desproteção sistêmica (FISCHER, 2013, p. 31), conforme se irá explicar.

Desse modo, parte da doutrina tem defendido a necessidade de se ampliar o estudo da teoria garantista que vem sendo difundido no Brasil ${ }^{6}$, o que tornaria mais coerente e racional a sua incidência, por meio do que se convencionou chamar de "garantismo penal integral"7. Douglas Fischer afirma se impõe o dever de visualizar os contornos integrais do sistema garantista se a Constituição prevê, explícita ou implicitamente, a necessidade de proteção de bens jurídicos e a proteção ativa dos interesses da sociedade e dos investigados/processados (2013, p. 38).

\footnotetext{
${ }^{3}$ Deve-se ter em mente que os paradigmas de Estado se sucedem, mas não se negam. Com isso, há uma agregação de demandas sociais, sem que as novas demandas se contraponham às anteriores.

${ }^{4}$ Ferrajoli (2006, p. 91) vislumbra a presença de dez axiomas no Sistema Garantista, denominando-os de princípios: 1) da retributividade; 2) da legalidade; 3 ) da necessidade; 4) da lesividade; 5) da materialidade; 6) da culpabilidade; 7) da jurisdicionariedade; 8) acusatório; 9) do ônus da prova; e 10) do contraditório. Importante esclarecer que, não sendo objeto do presente artigo o estudo aprofundado da Teoria do Garantismo Penal, cabe aqui apenas elencar os referidos princípios axiológicos, que representam, segundo o autor, "as regras do jogo fundamental do direito penal".

${ }^{5}$ Trata-se de expressão cunhada por Douglas Fischer, com o objetivo de ressaltar que na aplicação da teoria garantista no Brasil "evidencia-se desproporcionalmente (hiperbólico) e de forma isolada (monocular) a necessidade de proteção apenas dos direitos fundamentais individuais dos cidadãos que se vêem investigados, processados ou condenados" (FISCHER, 2013, p. 38). Selma Pereira Santana (2013, p. 552), neste mesmo sentido, utiliza a expressão "hipergarantismo", defendendo que "entre o hipergarantismo e o Direito Penal do Inimigo, o intérprete deve buscar o justo equilíbrio entre Garantismo e eficiência, de sorte que o movimento pendular da história não se distancie do ponto médio entre a proteção à liberdade e a segurança da sociedade".

${ }^{6}$ Selma Pereira Santana (2013, p. 552), com clara conotação crítica em relação a essa aplicação restrita da doutrina garantista no Brasil, utiliza-se da expressão "garantismo penal à brasileira".

${ }^{7}$ Novamente, dá-se crédito pela expressão a Douglas Fischer.
}

Revista de Direito Brasileira | São Paulo, SP | v. 16 | n. 7 | p. 186 - 210 | Jan./Abr. 2017 
A propósito, ainda dentro de um contexto de compreensão integral e sistemática da tutela estatal, Lênio Streck $(2008)^{8}$, citando Alessandro Baratta, bem esclarece que, no Estado Democrático de Direito, tem-se uma "política integral de proteção de direitos", isto é, afirma-se o dever de proteção estatal não somente no sentido clássico (proteção negativa) como limite do sistema punitivo, mas também no sentido de proteção positiva por parte do Estado.

Dentro dessa lógica sistemática (e integral) é que se defende que a interpretação do princípio da presunção de inocência - enunciado na ordem constitucional brasileira por meio da redação do art. 5, LVII, da Constituição Federal de 1988 ("ninguém será considerado culpado até o trânsito em julgado de sentença penal condenatória") - necessita de conformação racional, sem prejuízo da tutela do seu núcleo, com vistas a conferir maior efetividade ao processo penal e melhor compreensão do sistema acusatório.

A leitura do princípio da presunção de inocência, então, não se faz de modo isolado ou descontextualizado de demais corpos normativos que igualmente dão a ele conteúdo e alcance. Ao revés, é preciso cotejá-lo não só com aquilo que assegura seu sentido constitucional com o que permite, em sua prática, o respeito ao seu núcleo essencial.

Segundo Humberto Ávila (2013, p. 136), “princípios são prescrições finalísticas com elevado grau de generalidade material, sem consequências específicas previamente determinadas". Com efeito, conforme já se adiantou, a compreensão do alcance e do sentido dos princípios é variável segundo diversos fatores. Especificamente em relação ao princípio da presunção de inocência, em determinados momentos da história (do Brasil e do mundo), notadamente durante os períodos das práticas inquisitórias ${ }^{9}$ e do auge da Escola Positiva italiana $^{10}$, o seu alcance foi extirpado, tendo sido defendida uma verdadeira presunção de culpabilidade.

Importa esclarecer, no entanto, que é indefensável a rejeição ao princípio da presunção de inocência em um Estado que se pretenda minimamente democrático e de Direito ${ }^{11}$. É de se ressaltar, inclusive, que a própria lógica do sistema acusatório se baseia na garantia de uma presunção de inocência do suspeito, investigado, indiciado, acusado ou réu. Para Ferrajoli (2006, p. 506), "esse princípio fundamental de civilidade representa o fruto de uma opção garantista a favor da tutela da imunidade dos inocentes, ainda que ao custo da impunidade de algum culpado" $" 12$.

Nesse passo, cabe questionar: qual é o núcleo essencial do princípio da presunção de inocência? De forma bastante simples, mas suficiente ao que se pretende, pode-se dizer que a presunção de inocência implica que toda pessoa tem direito a ser presumida inocente, até prova em contrário. O que se busca evitar é a formulação de juízos precipitados de culpa em relação ao indivíduo. A Comissão Interamericana de Direitos Humanos, ligada à Organização dos Estados

\footnotetext{
${ }^{8}$ Expressa-se de forma incisiva o autor ao dizer "Insisto: já não se pode falar, nesta altura, de um Estado com tarefas de guardião de "liberdades negativas", pela simples razão - e nisto consistiu a superação da crise provocada pelo liberalismo - de que o Estado passou a ter a função de proteger a sociedade nesse duplo viés: não mais apenas a clássica função de proteção contra o arbítrio, mas, também, a obrigatoriedade de concretizar os direitos prestacionais e, ao lado destes, a obrigação de proteger os indivíduos contra agressões provenientes de comportamentos delitivos, razão pela qual a segurança passa a fazer parte dos direitos fundamentais (art. $5^{\circ}$, caput, da Constituição do Brasil)." (STRECK, 2008, destaques no original).

${ }^{9}$ A esse respeito, destaca Ferrajoli (2006, p. 506): "basta recordar que no processo penal medieval a insuficiência da prova, conquanto deixasse subsistir uma suspeita ou uma dúvida de culpabilidade, equivalia a uma semiprova, que comportava um juízo de semiculpabilidade e uma semicondenação a uma pena mais leve".

${ }^{10}$ Ferrajoli (2006, p. 507) destaca que Garofalo e Ferri consideravam "vazia", "absurda" e "ilógica" a fórmula da presunção de inocência.

${ }^{11}$ Ferrajoli (2006, p. 507) leciona que, para Francesco Carrara, o Princípio da Presunção de Inocência revelava postulado fundamental da ciência processual e pressuposto de todas as outras garantias do processo.

${ }^{12}$ Em Leviatã, Thomas Hobbes (apud Ferrajoli, 2006, p. 575) defendeu que "Todas as punições de súditos inocentes, sejam elas grandes ou pequenas, são contrárias à lei da natureza, pois a punição se dá só pela transgressão da lei, e por isso não pode existir pena para um inocente".
}

Revista de Direito Brasileira | São Paulo, SP | v. 16 | n. 7 | p. 186 - 210 | Jan./Abr. 2017 
Americanos (OEA), no "Relatório sobre o Uso da Prisão Preventiva nas Américas" (Informe sobre el Uso de la Prisión Preventiva en las Américas), preparado em 2013, destaca o seguinte (2013):

De todas las garantías judiciales propias del ámbito penal la más elemental es quizás la presunción de inocencia, expresamente reconocida sin salvedad ni excepción alguna por diversos instrumentos internacionales de derechos humanos, tales como la Declaración Universal de Derechos Humanos (Art. 11.1), el Pacto Internacional de Derechos Civiles y Políticos (Art. 14.2), la Declaración Americana (Art. XXVI) y la Convención Americana (Art. 8.2).

Nesse contexto, para que se possa compreender o sentido e o alcance da presunção de inocência, cumpre analisar como a referida garantia é tutelada em cada um desses instrumentos internacionais de proteção aos direitos humanos, dos quais o Brasil é signatário.

Adotando-se uma ordem cronológica crescente, o primeiro tratado internacional a se examinar é a Declaração Americana dos Direitos e Deveres do Homem, aprovada na Nona Conferência Internacional Americana, ocorrida em Bogotá, Colômbia, entre março e maio de 1948. A referida Declaração expressa a presunção de inocência dentro do que denomina de "direito a processo regular", estabelecendo no Artigo XXVI:

Parte-se do princípio que todo acusado é inocente, até provar-se-lhe a culpabilidade.

Toda pessoa acusada de um delito tem o direito de ser ouvida numa forma imparcial e pública, de ser julgada por tribunais já estabelecidos de acordo com leis preexistentes, e de que se lhe não inflijam penas cruéis, infamantes ou inusitadas.

Mais difundida, a Declaração Universal dos Direitos Humanos (DUDH), proclamada em 10 de dezembro de 1948 pela Assembleia Geral das Nações Unidas, em seu artigo XI, item 1, prevê que:

Todo ser humano acusado de um ato delituoso tem o direito de ser presumido inocente até que a sua culpabilidade tenha sido provada de acordo com a lei, em julgamento público no qual the tenham sido asseguradas todas as garantias necessárias à sua defesa.

O Pacto Internacional sobre Direitos Civis e Políticos, também adotado pela Assembleia Geral das Nações Unidas, no ano de 1966, enuncia em seu artigo 14, item 2, o seguinte: "Toda pessoa acusada de um delito terá direito a que se presuma sua inocência enquanto não for legalmente comprovada sua culpa.”. Ainda nessa linha, no item 5 do Artigo 14, o Pacto supracitado dispõe: "Toda pessoa declarada culpada por um delito terá direito de recorrer da sentença condenatória e da pena a uma instância superior, em conformidade com a lei”.

Por fim, a Convenção Americana sobre Direitos Humanos (Pacto de São José da Costa Rica), firmada em 1969 e ratificada pelo Brasil em 1992 ${ }^{13}$, expressa em seu texto, no Artigo 8, item 2, a presunção de inocência de forma bastante similar aos tratados internacionais citados acima, relacionando-a, ainda, a garantias mínimas.

2. Toda pessoa acusada de delito tem direito a que se presuma sua inocência enquanto não se comprove legalmente sua culpa. Durante o processo, toda pessoa tem direito, em plena igualdade, às seguintes garantias mínimas:

\footnotetext{
${ }^{13}$ A promulgação da Convenção Americana sobre Direitos Humanos no Brasil se deu por meio do Decreto $n^{\circ} 678$ de 06 de novembro de 1992.
} 
a. direito do acusado de ser assistido gratuitamente por tradutor ou intérprete, se não compreender ou não falar o idioma do juízo ou tribunal;

b. comunicação prévia e pormenorizada ao acusado da acusação formulada;

c. concessão ao acusado do tempo e dos meios adequados para a preparação de sua defesa;

d. direito do acusado de defender-se pessoalmente ou de ser assistido por um defensor de sua escolha e de comunicar-se, livremente e em particular, com seu defensor;

e. direito irrenunciável de ser assistido por um defensor proporcionado pelo Estado, remunerado ou não, segundo a legislação interna, se o acusado não se defender ele próprio nem nomear defensor dentro do prazo estabelecido pela lei; f. direito da defesa de inquirir as testemunhas presentes no tribunal e de obter o comparecimento, como testemunhas ou peritos, de outras pessoas que possam lançar luz sobre os fatos;

g. direito de não ser obrigado a depor contra si mesma, nem a declarar-se culpada; e

h. direito de recorrer da sentença para juiz ou tribunal superior.

Em linhas gerais, o que se verifica é que o núcleo da presunção de inocência se conecta com a necessidade de comprovação da culpa na forma da lei. Parece bastante preciso constatar que em nenhum desses tratados internacionais há a exigência de que a inocência somente possa ser afastada por meio do trânsito em julgado da decisão que impôs o juízo de culpabilidade sobre o condenado. Até porque, especialmente em relação aos recursos dirigidos às instâncias de estrito direito, como são as instâncias extraordinárias, vários países conformam os recursos ou instrumentos de acesso a essas Cortes como remédios de caráter rescisório ao que já decidido pelas instâncias ordinárias.

A presunção de inocência depende, isso sim, de uma condenação que tenha sido feita dentro das balizas do sistema acusatório, com o respeito ao devido processo legal (e, por conseguinte, aos princípios da ampla defesa e do contraditório), bem como em que se tenha oportunizado o duplo grau de jurisdição. Por esse motivo, faz-se necessário ressaltar a distinção entre a redação trazida pela Constituição Federal em seu art. 5\%, LXVII, e o núcleo do da presunção de inocência. A proteção a este núcleo deve ser irredutível, se se pretender a adoção de um processo penal pautado em um sistema acusatório e garantista.

No entanto, entende-se que a leitura que muitos juristas vêm fazendo do texto constitucional merece conformação não só em nome de uma maior efetividade do processo penal mas para também buscar uma maior racionalidade do sistema acusatório adotado.

O princípio traz em si uma presunção. Essa presunção (de inocência) é afastada se, mediante um devido processo legal, há a comprovação da culpa pela Acusação, de forma a convencer o magistrado, para além de qualquer dúvida razoável, da prática de conduta delituosa (não justificada ou exculpada), a ensejar, aí sim, uma condenação penal por meio de uma decisão fundamentada. É que a presunção de inocência não é (nem poderia ser, sob pena de se desestabilizar o próprio funcionamento do corpo social ${ }^{14}$ ) uma presunção absoluta, motivo pelo qual provas (robustas) em sentido contrário são capazes de elidí-la.

Nesse sentido, Frischeisen, Garcia e Gusman (2013, p. 455), apontam que "Não se trata, portanto, de uma presunção absoluta, sendo derrogada pelas próprias provas produzidas num processo em que se observam o contraditório e a ampla defesa". A ampliar a proteção a esse Princípio tão caro ao Estado Democrático de Direito, possibilita-se à defesa do condenado a promoção de uma reanálise profunda dos fatos e das provas por um colegiado de magistrados, por meio da interposição de um recurso de apelação, para que, somente após a confirmação da

${ }^{14}$ Trata-se da "função conservadora" ou "de controle social" do Direito Penal (BATISTA, 2011, p. 21). Revista de Direito Brasileira | São Paulo, SP | v. 16 | n. 7 | p. 186 - 210 | Jan./Abr. 2017 
sentença condenatória penal por um acórdão, se possa impor o início do cumprimento de uma pena (privativa de liberdade ou restritiva de direito).

Em suma, cabe (re)consignar de forma bastante clara: o núcleo da presunção de inocência, garantia indispensável ao próprio Estado Democrático de Direito, não esbarra na necessidade do trânsito em julgado da decisão condenatória, mas tangencia o imperativo da comprovação da culpabilidade na forma da lei e o duplo grau de jurisdição.

Assim, impende analisar as nuances que envolvem o cumprimento da pena após a confirmação da sentença penal condenatória por acórdão condenatório, ainda não transitado em julgado.

\section{A EXECUÇÃO PROVISÓRIA DA PENA}

A compreensão da chamada execução provisória da pena não pode se dissociar das considerações sobre a pena e a legitimidade da intervenção penal como um todo. Afinal, o direito processual penal e sua modelagem normativos não pode se dissociar das razões últimas do direito material que veicula.

A adequação da sanção penal como instrumento de reação estatal face ao cometimento de um delito é objeto de profundas discussões dentro do sistema das ciências criminais ${ }^{15}-$ Criminologia, Direito Penal e Política Criminal -, notadamente quando se circunscreve o exame da pena privativa de liberdade ${ }^{16}$.

Desse modo, não se ignora a crítica à função do Direito Penal como instrumento de controle social ${ }^{17}$, como ferramenta de garantia da ordem econômica e social, tampouco as deficiências do combate ao crime e o problema das cifras ocultas (BATISTA, 2011, p. 21). No entanto, para desenvolvimento dos fins aqui propostos, se estabelece que o Direito Penal exerce uma importante missão de manutenção do funcionamento do corpo social - inclusive evitando reações particulares de vingança -, de tutela de bens jurídicos e de limitação da intervenção estatal (BATISTA, 2011, p. 20, p. 108; FERRAJOLI, 2006, p. 311).

Segundo Claus Roxin (2006, p. 28), o Direito Penal do futuro, ao levar adiante os postulados iluministas, e sob os pressupostos de um mundo completamente modificado, tornarse-á cada vez mais um instrumento de direcionamento social (entenda-se: ferramenta de controle social) totalmente secularizado, com o fim de chegar a uma síntese entre a garantia da paz, o sustento da existência e a defesa dos direitos do cidadão.

Ao apresentar o garantismo penal, Ferrajoli endossa a doutrina justificacionista do Direito Penal, para defender a forma jurídica da pena, indicando-a como "técnica institucional de minimização da reação violenta" ao desvio socialmente não tolerado e "garantia do acusado contra os arbítrios, os excessos e os erros conexos a sistemas não jurídicos de controle social" (2006, p. 230-232). Sobre o tema, Salo de Carvalho (2013, p. 234) observa que Ferrajoli abdica das teorias negativas e responde de forma afirmativa quanto à necessidade de punição aos desvios criminalizados. Acrescenta que o jurista italiano exclui os projetos abolicionistas, para sustentar que, na ausência de resposta penal formalizada pelo Estado, os grupos sociais retornariam a

\footnotetext{
${ }^{15}$ Ferrajoli (2006, p. 230) adverte que "O problema da justificação da pena, ou seja, do poder de uma comunidade política qualquer de exercitar uma violência programada sobre um de seus membros, é, talvez, o problema clássico, por excelência, da filosofia do direito.”.

${ }^{16}$ Alessandro Baratta (2011, p. 203), dentre outros, defende a abolição da instituição carcerária, diante do fracasso histórico da prisão para fins de controle da criminalidade e de reinserção do desviante na sociedade, assim como de sua contribuição ao processo de marginalização dos indivíduos isolados e ao esmagamento de setores da classe operária.

${ }^{17}$ Entende Lola Aniyar de Castro (apud BATISTA, 2011, p. 21) que o controle social "não passa da predisposição de táticas, estratégias e forças para a construção da hegemonia, ou seja, a busca da legitimação ou para assegurar o consenso; em sua falta, para a submissão forçada daqueles que não se integram à ideologia dominante".
}

Revista de Direito Brasileira | São Paulo, SP | v. 16 | n. 7 | p. 186 - 210 | Jan./Abr. 2017 
práticas pré-civilizadas ou dotariam medidas de controle tecnológico tendenciosamente autoritárias (CARVALHO, 2013, p. 234).

Assim, tomando como necessária a construção de um discurso de legitimação da intervenção penal, de modo que a pena incida aos agentes que venham a cometer crime, a lição de Cesare Beccaria permanece atual e reveladora, após mais de duzentos e cinquenta anos. Para o pensador iluminista, a presteza das penas é mais útil, porque quanto menor for o intervalo de tempo que passa entre a pena e o malfeito, tanto será mais forte e mais duradoura no ânimo humano a associação dessas duas ideias, delito e pena, de forma que sejam considerados de modo imanente um como causa e a outra como efeito necessário e inafastável (1973, p. 50).

É nesse contexto que se passa a analisar a execução da pena imposta por acórdão penal condenatório, antes do trânsito em julgado - a conhecida execução provisória da pena.

A análise quanto à possibilidade ou não de se iniciar o cumprimento da pena após a condenação em segundo grau, no cenário jurídico brasileiro, exige, necessariamente, uma reflexão acerca do texto prescrito no art. 5, LVII, da Constituição Federal, a saber, "ninguém será considerado culpado até o trânsito em julgado de sentença penal condenatória". A literalidade da redação adotada aqui no Brasil parece levar à conclusão de que a execução provisória da pena estaria vedada, uma vez que poder-se-ia compreender que a produção de efeitos decorrentes uma condenação estaria suspensa até o advento do trânsito em julgado da decisão judicial que fixou a referida responsabilidade penal.

No entanto, é prudente relembrar aquilo que já foi dito: a interpretação meramente literal reduz a efetividade do sistema, atravanca o seu funcionamento operacional e impede a realização de outros princípios caros à Constituição. É imperioso que se privilegie uma interpretação sistemática, que consiga harmonizar, unificar e concretizar o desenho constitucional, sob pena de se promover a incongruência sistêmica.

A propósito, Konrad Hesse (2009, p. 108-109) leciona que

A interpretação constitucional é "concretização" (Konkretisierung). Precisamente aquilo que não aparece, de forma clara, como conteúdo da Constituição é o que deve ser determinado mediante a incorporação da "realidade" de cuja ordenação se trata. Nesse sentido, a interpretação constitucional tem caráter criativo: o conteúdo da norma interpretada só se completa com a sua interpretação; mas, veja-se bem, só em tese possui caráter criativo, pois a atividade interpretativa fica vinculada à norma.

Não se nega, assim, que, embora seja necessário por meio de interpretação conferir concretude ao conteúdo da Constituição, a atividade hermenêutica não pode ser exercida de forma ilimitada, encontrando barreiras normativas. No entanto, "Normas não são textos nem o conjunto deles, mas os sentidos construídos a partir da interpretação sistemática de textos normativos" (ÁVILA, 2013, p. 33). Nessa conjuntura de avaliação da difícil e complexa tarefa do intérprete, pode-se recordar a constatação de Streck (2012, p. 72):

Sempre há algo que escapa, que fica de fora daquilo que foi dito (no não dito). A tarefa do hermeneuta, então, será trazer à tona esse não dito, ou seja, aquilo que sustenta o próprio enunciado. É inútil qualquer esforço para tentar retirar das palavras ou dos textos uma essência que lhes qualifique o sentido. $O$ sentido não vem das palavras, nem está nas palavras, mas são as palavras que se articulam a partir do sentido.

Não é simples definir o que se encontra dentro do espaço de conformação da norma e o que caracteriza excesso de subjetivismo do intérprete, tampouco separar as consequências limitadoras de um texto do núcleo de proteção da norma dele decorrente. Ciente dessa 
dificuldade, entende-se adequado defender uma intepretação que considere não somente um dispositivo da Constituição Federal, mas toda a sua unidade, o que se faz com apoio, novamente, na doutrina de Konrad Hesse (2009, p. 113):

A relação e interdependência existentes entre os distintos elementos da Constituição obrigam a que, em nenhum caso, se contemple a norma isoladamente, mas, ao contrário, sempre no conjunto em que ela deve estar situada; todas as normas constitucionais hão de ser interpretadas de tal modo que se evitem contradições com outras normas da Constituição.

No exame quanto à possibilidade de se promover a execução provisória, e partindo de uma interpretação em busca da Unidade da Constituição, se propõe os seguintes questionamentos iniciais: o que é trânsito em julgado? Existe coisa julgada no processo penal?

Uma primeira ideia deve ficar clara: a Constituição Federal, embora adote em seu texto as expressões ora analisadas, não apresenta qualquer definição do que seja trânsito em julgado ou coisa julgada. Como se sabe, a coisa julgada de uma decisão é determinada pelo seu trânsito em julgado. No âmbito legal, encontra-se conceituação na Lei de Introdução às Normas do Direito Brasileiro (Decreto-lei $n^{\circ} 4.657 / 42$ ) que, em seu art. $6^{\circ}, \S 1^{\circ}$, prevê: "Chama-se coisa julgada ou caso julgado a decisão judicial de que já não caiba recurso.”. Com o objetivo de situar temporalmente a referida previsão legislativa, anota-se que tal definição não decorre da redação original da Lei de Introdução, tendo sido incluída pela Lei no 3.238 de 1957. Para a doutrina, utilizando-se do magistério do renomado processualista, a coisa julgada é "a imutabilidade da sentença de mérito e de seus efeitos" (BEDAQUE, 2009, p. 132). Em que pese o referido conceito pareça não abrir espaço para maiores desdobramentos, é importante observar que a coisa julgada depende fundamentalmente da natureza da situação da vida sobre a qual o provimento jurisdicional projeta seus efeitos (BEDAQUE, 2009, p. 125) ${ }^{18}$.

É nesse contexto que se deve atentar para o fato de que a sentença penal condenatória, dentro da sistemática do ordenamento brasileiro, não observa esse conceito de imutabilidade (BEDAQUE, 2009, p. 125). Afinal, a qualquer tempo pode ser atacada por meio de uma ação de impugnação, como o Habeas Corpus ou a Revisão Criminal.

Assim, se o conceito de coisa julgada fosse entendido como a impossibilidade absoluta de se alterar uma decisão, no âmbito penal, nunca haveria de se falar em decisão (condenatória) ${ }^{19}$ transitada em julgado, porquanto sempre presente a possibilidade de revisão. Com isso, possível seria concluir que a execução penal seria sempre provisória (FRISCHEISEN, GARCIA e GUSMAN, 2013, p. 455).

Por essas razões, permite-se assentar que a sentença penal condenatória não se reveste da qualidade de imutabilidade de forma absoluta. Se a sentença penal condenatória sempre se sujeita a uma possível alteração, exigir a imutabilidade de uma decisão dessa natureza é inviabilizar qualquer execução da pena. A toda evidência, não se reveste de constitucionalidade uma conclusão nesse sentido, inclusive porque, como se sabe, a Constituição Federal estabelece expressos mandados de criminalização (FRISCHEISEN, GARCIA e GUSMAN, 2013, p. 456).

Outra interpretação possível, ainda no que diz respeito ao início da execução da pena, é se falar em coisa julgada parcial ou em relação à matéria fática, já que os recursos extraordinários (REsp e RE) não se destinam ao reexame de fatos e provas, motivo pelo qual a

\footnotetext{
${ }^{18}$ Acrescenta o autor: "Imprescindível, portanto, para bem precisar o exato alcance da imutabilidade determinada pelo trânsito em julgado, bem como das consequências ligadas ao instituto da coisa julgada, identificar precisamente a relação jurídica material sobre que incidirá o provimento judicial" (BEDAQUE, 2009, p. 125).

${ }^{19}$ Por outro lado, não se pode negar essa qualidade de imutabilidade às decisões absolutórias.
} 
discussão acerca de ambos, e por conseguinte da própria materialidade e autoria, já teria sido definida $^{20}$.

Conforme se verá a seguir, no julgamento do HC 126.292, no voto do Ministro Relator Teori Zavascki, a referida ideia foi tangenciada, nos termos em que se transcreve abaixo:

Noutras palavras, com o julgamento implementado pelo Tribunal de apelação, ocorre espécie de preclusão da matéria envolvendo os fatos da causa. Os recursos ainda cabíveis para instâncias extraordinárias do STJ e do STF recurso especial e extraordinário - têm, como se sabe, âmbito de cognição estrito à matéria de direito. Nessas circunstâncias, tendo havido, em segundo grau, um juízo de incriminação do acusado, fundado em fatos e provas insuscetíveis de reexame pela instância extraordinária, parece inteiramente justificável a relativização e até mesmo a própria inversão, para o caso concreto, do princípio da presunção de inocência até então observado.

Nesse mesmo sentido, Fernando Brandini Barbagalo (2015, p. 113) adverte que, dado o caráter vinculado dos recursos extraordinários (especial e extraordinário), com hipóteses legais pré-determinadas, seria possível sustentar a definitividade da decisão quanto ao aspecto fático já definido pela instância ordinária. Complementa tal raciocínio o fato de que o STF e o STJ, dentro da própria organização funcional estabelecida pela Constituição, não exercem papel de instâncias revisionais $^{21}$, haja vista que só conhecem de recursos em causas decididas ${ }^{22}$, em única ou última instância, sendo requisito, portanto, o esgotamento das vias ordinárias. Assim, os recursos especial e extraordinário pressupõem uma decisão definitiva da justiça local (BARBAGALO, 2015, p. 114).

Desse modo, adotando-se a compreensão ora assinalada, o texto constitucional não obsta que se inicie o cumprimento da pena após a condenação (definitiva) nas vias ordinárias, isto é, quando o Tribunal de Justiça ou o Tribunal Regional Federal exerce juízo quanto ao fato e provas constantes do processo e impõe ao réu a responsabilização penal. Essa proposição preserva o núcleo da presunção de inocência, estabelecido como a comprovação da culpa com a observância do devido processo legal, incluído neste significante o respeito ao contraditório, à ampla defesa e ao duplo grau de jurisdição.

Para que fique claro: o que se defende no presente trabalho é que a execução provisória da pena, a partir do encerramento da instância ordinária, não substancia afronta à presunção de inocência, ainda que se considere a dimensão literal do que estabelecido no art. $5^{\circ}$, LVII, da Constituição, por força da inafastável compreensão sistemática do traçado normativo da ordem constitucional.

Aliás, nessa orientação, o "Conjunto de Principios para la protección de todas las personas sometidas a cualquier forma de detención o prisión”, formulado pela já mencionada Comissão Interamericana de Direitos Humanos, vinculada à OEA, preceitua em seu Princípio 36 que: "Se presumirá la inocencia de toda persona sospechosa o acusada de un delito y se la

\footnotetext{
${ }^{20}$ Nesse contexto, deve-se recordar que outros textos constitucionais que exigem o trânsito em julgado para o afastamento da presunção de inocência possuem recursos extraordinários que se voltam contra a coisa julgada, ou seja, que possuem efeito rescisório. É o caso de Portugal (art. 32, item 2) e da Espanha (art. 245, n. 3.). A matriz constitucional brasileira se espelhou na Constituição portuguesa. A incongruência é que, no Brasil, a recorribilidade extraordinária é impeditiva da coisa julgada.

${ }^{21}$ Tourinho Filho (apud BARBAGALO, 2015, p. 114) destaca bem essa ideia: "Insta acentuar que o fato de termos os recursos extraordinário e especial, segundo dispõem os arts. 102, III, e art. 105, III, ambos da CF, não significa que tenhamos um triplo grau de jurisdição, mesmo porque o STF e o STJ não examinam, nesses recursos, matéria fática. Limitam-se a constatar se a Constituição foi desautorada ou se a Lei Federal foi desrespeitada. Só.”.

${ }^{22}$ Causa decidida em última instância significa que o processo foi julgado extinto, com ou sem julgamento do mérito, e ordinariamente revisto por um Tribunal (BARBAGALO, 2015, p. 115).
}

Revista de Direito Brasileira | São Paulo, SP | v. 16 | n. 7 | p. 186 - 210 | Jan./Abr. 2017 
tratará como tal mientras no haya sido probada su culpabilidad conforme al derecho en un juicio público en el que haya gozado de todas las garantías necesarias para su defensa" (1988).

Destaca-se do princípio citado acima a seguinte ideia: o acusado ou suspeito será tratado como inocente enquanto sua culpabilidade não tenha sido comprovada conforme o direito em um julgamento público com todas as garantias necessárias para a sua defesa. Portanto, o entendimento ora sustentado encontra amplo respaldo na normativa do Direito Internacional.

Ainda dentro do propósito de exploração do tema, mostra-se pertinente perguntar: o que é ser tratado como inocente (ou como não culpado)?

Cabe, antes de se prosseguir no desdobramento do tema, a advertência de que, para os fins do presente estudo, é desimportante a discussão quanto a eventuais distinções entre princípio da presunção de inocência, da presunção de não culpabilidade ou do estado de inocência (e outros). Trata-se de representativo esforço hermenêutico com pouca ou nenhuma consequência prática. Portanto, em que pese o texto do art. $5^{\circ}$, LVII, da Constituição utilize a expressão "ninguém será considerado culpado", entende-se que este exprime inequivocamente a presunção de inocência.

A presunção de inocência se desdobra em duas regras (principais ${ }^{23}$ ): uma regra de tratamento e uma regra probatória, conforme bem delineado por Luiz Flávio Gomes (2011). Na mesma linha, Pacelli (2011, p. 44) leciona que a presunção de inocência impõe ao Poder Público a observância de regra de tratamento, a vedar a imposição de restrições pessoais fundadas exclusivamente na possibilidade de condenação, e de regra probatória, a impor todo o ônus da prova sobre o fato e a autoria exclusivamente à acusação.

A regra de tratamento particularmente interessa ao tema da prisão processual decorrente do encerramento da instância ordinária. Ela prescreve que o réu deverá ser tratado como inocente no curso do processo, até que seja afastada a presunção de sua inocência. Nesse contexto, se a regra de tratamento fosse tutelada de forma absoluta, inviável seria a decretação de qualquer prisão cautelar (ou demais medidas que visem assegurar o resultado final do processo penal), tendo em vista que a prisão - provisória ou definitiva - não se decreta em desfavor de um inocente.

Sobre o cotejo da prisão processual com a regra de tratamento oriunda da presunção de inocência, Streck $\left(2012\right.$, p. 77) ${ }^{24}$ adverte que há possibilidade de aplicação principiológica da presunção de inocência, para suspendê-la como regra de presunção, "nos casos em que o acusado reúne em torno de si circunstâncias suficientes para afirmar que ele é, possivelmente, o autor do delito".

Gilmar Mendes (2015) enfatiza que, apesar de a Constituição estabelecer que ninguém deverá ser considerado culpado, não há uma delimitação precisa do que seria esse tratamento, o que, em sua reflexão, dependeria de uma atuação do legislador. Ele aponta, igualmente, que a previsão constitucional não impede um tratamento tanto mais gravoso quanto mais afirmada a culpa do acusado, ressaltando que o regulamento legal opera nesse sentido. Sobre essa compreensão gradativa da presunção de inocência, vale registrar textualmente o escólio:

No que se refere à presunção de não culpabilidade, seu núcleo essencial impõe o ônus da prova do crime e sua autoria à acusação. Sob esse aspecto, não há

\footnotetext{
23 Aury Lopes Jr (2013, p. 228), citando Vegas Torres, ensina que a presunção de inocência aponta para três principais manifestações integradoras. Acrescenta-se aqui a lição de que a presunção "É um princípio fundante, em torno do qual é construído todo o processo penal liberal, estabelecendo essencialmente garantias para o imputado frente à atuação punitiva estatal”.

${ }^{24}$ Em que pese a citação, não se desconhece o posicionamento pessoal de Streck contrário ao que fixado pelo STF no julgamento do HC 126.292. Aliás, o jurista figura como um dos subscritores da ação declaratória de constitucionalidade n. 43, ajuizada pelo Conselho Federal da Ordem dos Advogados do Brasil, em face do disposto no art. 283 do CPP, e tem divulgado diversos escritos com duras críticas ao posicionamento firmado pelo STF sobre o tema da execução provisória da pena.
}

Revista de Direito Brasileira | São Paulo, SP | v. 16 | n. 7 | p. 186 - 210 | Jan./Abr. 2017 
maiores dúvidas de que estamos falando de um direito fundamental processual, de âmbito negativo.

Para além disso, a garantia impede, de uma forma geral, o tratamento do réu como culpado até o trânsito em julgado da sentença. No entanto, a definição do que vem a ser tratar como culpado depende de intermediação do legislador.

Ou seja, a norma afirma que ninguém será considerado culpado até o trânsito em julgado da condenação, mas está longe de precisar o que vem a ser considerar alguém culpado.

O que se tem é, por um lado, a importância de preservar o imputado contra juízos precipitados acerca de sua responsabilidade. Por outro, uma dificuldade de compatibilizar o respeito ao acusado com a progressiva demonstração de sua culpa.

Disso se deflui que o espaço de conformação do legislador é lato. A cláusula não obsta que a lei regulamente os procedimentos, tratando o implicado de forma progressivamente mais gravosa, conforme a imputação evolui. Por exemplo, para impor a uma busca domiciliar, bastam "fundadas razões" - art. 240, §1o, do CPP. Para tornar o implicado réu, já são necessários a prova da materialidade e indícios da autoria (art. 395, III, do CPP). Para condená-lo, é imperiosa a prova além de dúvida razoável (MENDES, 2015).

O tratamento do imputado como se inocente fosse pode ser, presentes os requisitos legais para tanto, gradativamente mitigado ao avançar do processo penal ordinário. Isso não revela a adoção de um princípio de culpabilidade, uma vez que somente diante de uma progressiva comprovação de culpa pela acusação é que se torna possível a inversão da presunção de inocência.

Em continuidade, a segunda regra derivada da presunção de inocência, como adiantado acima, é a regra probatória ${ }^{25}$, cujo efeito incide sobre a distribuição do ônus probatório no processo penal. Nesse aspecto, a presunção de inocência do acusado impõe que o ônus da prova recaia todo sobre a acusação (GOMES, 2011). Aury Lopes Jr. (2013, p. 230) estabelece que esse é um "dever de tratamento imposto - primeiramente - ao juiz, determinando que a carga da prova seja inteiramente do acusador (pois, se o réu é inocente, não precisa provar nada) e que a dúvida conduza inexoravelmente à absolvição".

É precisamente dentro desse contexto que se defende que inviabilizar a execução da pena após a condenação em segundo grau rompe com a lógica do sistema acusatório. Aguardar o trânsito em julgado nas instâncias extraordinárias não se revela indispensável à preservação do núcleo da presunção de inocência. Esclarecedora é a lição de Aury Lopes Jr (2013, p. 228) no sentido de que se pode extrair também da presunção de inocência a ideia de que o convencimento judicial é construído em contraditório. Com efeito, o processo penal pautado em um modelo acusatório se legitima na exata medida em que sua resposta se dê em observância das garantias constitucionais penais. Para Aury Lopes Jr. (2013, p. 161), "o fundamento legitimante da existência do processo penal democrático é sua instrumentalidade constitucional, ou seja, o processo enquanto instrumento a serviço da máxima eficácia de um sistema de garantias mínimas" (destaque no original).

Dentro do cenário de um processo penal acusatório, não se mostra absurdo defender que, após a imputação de responsabilidade penal por meio de um devido processo legal desenvolvido com a observância das garantias (constitucionais) do sistema acusatório, permita-se a execução da pena imposta e revista no segundo grau de jurisdição, ainda que pendentes de julgamento

\footnotetext{
${ }^{25}$ No julgamento do HC 84.078, em 2009, a Ministra Ellen Gracie, ressaltando a importância da regra probatória, consignou que "o domínio mais expressivo de incidência do princípio da não-culpabilidade é o da disciplina jurídica da prova. $\mathrm{O}$ acusado deve, necessariamente, ser considerado inocente durante a instrução criminal - mesmo que seja réu confesso de delito praticado perante as câmeras de TV e presenciado por todo o país". Essa constatação foi retomada por Zavascki no julgamento do HC $126.292 \mathrm{em} 2016$.
}

Revista de Direito Brasileira | São Paulo, SP | v. 16 | n. 7 | p. 186 - 210 | Jan./Abr. 2017 
eventuais recursos extraordinários. Por duas vezes, de forma ampla, os fatos e as provas apresentados pela acusação e contraditados pela defesa foram examinadas por um julgador independente, alheio e imparcial. Além disso, para que este juízo proferisse uma decisão condenatória, é imprescindível que o seu convencimento quanto à culpa do imputado supere qualquer dúvida razoável e seja explicitado de forma fundamentada (PRADO, 2001).

Por essas razões, não se vislumbra a correção do argumento de que a execução provisória da pena importe em um "jogar no lixo" dos "direitos assegurados a todo cidadão brasileiro que responde a um processo criminal" (BITTENCOURT, 2016). Mais parece ser o caso de se concordar com o alerta dado por Vladimir Aras (2016), para que não "caiamos em histeria", como se o tema em análise conduzisse o Estado brasileiro "a caminho de uma ditadura fascista".

Em síntese, num sistema acusatório, a responsabilidade penal de alguém só pode ser imposta por meio de um processo penal em que se limitou a pretensão punitiva do Estado e se garantiu a paridade de armas. Ao réu se deve assegurar o exercício do contraditório e da ampla defesa. À acusação incumbe demonstrar a culpa, vedado o uso de provas ilícitas. Consequentemente, a condenação só pode ser baseada em um juízo de certeza - já que a dúvida favorece o réu - e esse julgamento só pode ser prolatado por um magistrado alheio, imparcial e independente, a quem se impõe o dever de fundamentação, com base no direito objetivo positivado na ordem jurídica.

Portanto, a adoção de um modelo acusatório de processo penal, dentro do qual se inclui a garantia da presunção de inocência - nos moldes delineados nos tópicos acima - não é incompatível com a execução provisória da condenação, após o exercício do duplo grau de jurisdição. Aliás, muito mais que isso, é extremamente lógico que um juízo de condenação (duplamente) obtido, por meio de um processo assegurador de todas essas garantias, produza os seus devidos efeitos.

Passemos, pois, à análise das decisões proferidas pelo STF no julgamento do HC 84.078, de 2009, no HC 126.292, de 2016, ambos paradigmáticos quanto ao tema deste artigo, e mais recentemente a negativa de concessão de medida acauteladora nas Ações declaratórias de constitucionalidade n. 43 e 44, julgadas em 5 de outubro de 2016.

\section{AS DECISÕES DO STF}

Até o ano de 2009, já sob a vigência da atual ordem constitucional, a jurisprudência do Supremo Tribunal Federal era no sentido da possibilidade da execução provisória da sentença penal condenatória confirmada em segunda instância, ainda que pendente o julgamento de recursos extraordinários, não detentores de efeito suspensivo.

Em fevereiro de 2009, seguindo o posicionamento que vinha sendo adotado nas Turmas no tocante às penas restritivas de direitos ${ }^{26}$, o Tribunal, em decisão proferida por maioria do Pleno no julgamento do HC 84.078-7/MG, entendeu que a interpretação mais adequada a ser dada à presunção de inocência vedava a possibilidade de se executar provisoriamente uma pena de prisão imposta em sentença condenatória não transitada em julgado. Decidiu o STF, naquela oportunidade, que a prisão antes do trânsito em julgado da condenação somente poderia ser decretada a título cautelar. Em seu voto, o Ministro Relator Eros Grau consignou o seguinte:

Nas democracias, mesmo os criminosos são sujeitos de direitos. Não perdem essa qualidade, para se transformarem em objetos processuais. São pessoas,

\footnotetext{
${ }^{26}$ Em relação à pena restritiva de direitos, as Turmas do STF já estavam interpretando o art. 147 da LEP no sentido de que não seria possível a execução da sentença sem o seu trânsito em julgado. Cita-se como exemplo o HC 88.413 de 2006.
} 
inseridas entre aquelas beneficiadas pela afirmação constitucional da sua dignidade (art. 1. ${ }^{\circ}$, III, da Constituição do Brasil). É inadmissível a sua exclusão social, sem que sejam consideradas, em quaisquer circunstâncias, as singularidades de cada infração penal, o que somente se pode apurar plenamente quando transitada em julgado a condenação de cada qual.

A esse respeito, repisa-se a conclusão do tópico anterior: a sentença penal condenatória não se reveste da qualidade de imutabilidade de forma absoluta, razão pela qual a exigência de um trânsito em julgado irretocável levaria à impossibilidade de qualquer execução penal. Ademais, não parece correto falar em "apuração plena" dentro de um juízo feito por uma instância extraordinária, cujo âmbito de atuação é restrito à análise de teses jurídicas (no STF, a questões de direito em que se vislumbre uma repercussão geral), tutelando-se o direito subjetivo do recorrente apenas de maneira indireta (BARBAGALO, 2015, p. 114).

Outra análise feita pelo STF, ao tempo do julgamento do HC 84.078-7/MG, em 2009, foi a de que os preceitos da Lei n. 7.210 de 1984 (Lei de Execução Penal - LEP) sobrepor-se-iam temporal e materialmente ao disposto no art. 637 do Código de Processo Penal. O art. 637 do CPP possui a seguinte redação: "O recurso extraordinário não tem efeito suspensivo, e uma vez arrazoados pelo recorrido os autos do traslado, os originais baixarão à primeira instância, para a execução da sentença". O art. 105 da LEP, por sua vez, estabelece que: "Transitando em julgado a sentença que aplicar pena privativa de liberdade, se o réu estiver ou vier a ser preso, o juiz ordenará a expedição de guia de recolhimento para a execução". Entendeu o Ministro Relator que a redação da LEP estaria de acordo com a Constituição Federal (daí a prevalência material), bem como que, datando de 1984, a disposição da Lei de Execução Penal "derrogaria"27 o art. 637 do CPP (originário da redação de 1941).

Cabem aqui duas observações. A primeira, é que, da forma como redigido, o próprio art. 105 da LEP não impede a execução provisória. Isso porque é possível realizar a interpretação seguinte: transitada em julgado a sentença que aplicar pena privativa de liberdade, se o réu estiver preso (por execução provisória), o juiz ordenará a expedição de guia de recolhimento para a execução (definitiva). A segunda é que, posteriormente à LEP (de 1984), a Lei 8.038 de 1990, em seu art. 27, § $2^{\mathrm{o} 28}$, reafirmou o art. 637 do CPP ao dispor que "Os recursos extraordinário e especial serão recebidos no efeito devolutivo." ${ }^{29}$. Essa segunda percepção não escapou ao Ministro Relator, mas ele entendeu que "A supressão do efeito suspensivo desses recursos é expressiva de uma política criminal vigorosamente repressiva".

Desse modo, a sobreposição material e temporal vislumbrada não possui a clareza propagada no voto do HC 84.078 e encontra argumentos em sentido contrário, notadamente pelo fato de que o entendimento que prevaleceu em 2009 optou por desconsiderar a norma trazida pela Lei 8.038/90, posterior à LEP e confirmatória do texto do art. 637 do CPP, como mencionado. Parece oportuno recordar Gadamer, para quem "nenhum enunciado possui apenas um sentido unívoco, mas sim um sentido motivado" (2002, p. 210).

Em fevereiro de 2016, o Pleno do STF, no julgamento do HC 126.292, revisita o entendimento então estabelecido em 2009, para afirmar a compatibilidade do disposto no art. 637

\footnotetext{
${ }^{27}$ Não foi utilizada essa expressão textualmente no voto condutor proferido pelo Ministro Eros Grau, mas é essa a conclusão a que se chega da leitura dos argumentos ali enumerados.

${ }^{28} \mathrm{O}$ artigo foi revogado pela Lei 13.105/15 (novo Código de Processo Civil), mas a ausência de efeito suspensivo se mantém. É o que se deduz do $\S 5 .^{\circ}$ do art. 1.029: "§ 5..$^{\circ} \mathrm{O}$ pedido de concessão de efeito suspensivo a recurso extraordinário ou a recurso especial poderá ser formulado por requerimento dirigido".

${ }^{29}$ Se o recurso é recebido somente no efeito devolutivo - e não no duplo efeito - é possível a sua execução provisória. É esse, propriamente, o conceito de execução provisória, conforme ressalta Maria Lúcia Karam (2009, p. 54): "no ordenamento processo penal brasileiro, por definição legal, uma execução é provisória quando pendente impugnação da sentença mediante recurso ao qual não foi atribuído efeito suspensivo, denominando-se definitiva a execução da sentença transitada em julgado (definições vindas no $\S 1^{\circ}$ do artigo 475-I do Código de Processo Civil [de 1973])".
}

Revista de Direito Brasileira | São Paulo, SP | v. 16 | n. 7 | p. 186 - 210 | Jan./Abr. 2017 
do CPP com a presunção de inocência positivada na Constituição. Anote-se que o motivo que levou à alteração da jurisprudência que vinha sendo adotada - cujos efeitos deletérios foram certamente sentidos pelas Cortes Superiores -, bem como a legitimidade do Supremo Tribunal Federal para promover essa atualização, não serão objeto do presente trabalho.

No HC 126.292/SP, de relatoria do Ministro Teori Zavascki, o Tribunal restaurou a orientação tradicional da Corte no sentido de que: "a execução provisória de acórdão penal condenatório proferido em grau de apelação, ainda que sujeito a recurso especial ou extraordinário, não compromete o princípio constitucional da presunção de inocência". Ironicamente, o julgamento foi proferido pelo Pleno com o mesmo "placar" julgamento de 2009, mas agora em sentido oposto (7 votos favoráveis e 4 contrários à nova orientação). Votaram a favor da execução provisória da pena os Ministros Teori Zavascki, Edson Fachin, Roberto Barroso, Dias Toffoli, Gilmar Mendes, Cármen Lúcia e Luiz Fux. Contrários à orientação proposta pelo relator e em favor da continuidade do entendimento fixado em 2009, Celso de Mello, Marco Aurélio, Rosa Weber e Ricardo Lewandowski.

O Ministro Relator, Teori Zavascki, ressaltou em seu voto que no, exame feito pelo Tribunal de segunda instância, fica definitivamente exaurida ${ }^{30}$, de ordinário, a análise sobre os fatos e as provas da causa, com eventual fixação da responsabilidade penal do acusado. Consignou Zavascki que o duplo grau de jurisdição é concretizado no julgamento da apelação ${ }^{31}$, diante da reanálise da sentença em sua inteireza, e não por ocasião da decisão em REsp ou RE. Isso porque os recursos excepcionais não possuem devolutividade ampla, uma vez que não permitem o questionamento da matéria fático-probatória. O Relator lembrou, ainda, que os recursos extraordinários se prestam, de forma precípua, à preservação da higidez do sistema normativo (e não analisar a justiça ou injustiça), o que é corroborado pela própria exigência de demonstração da repercussão geral para conhecimento do RE. Com isso, haveria uma "espécie de preclusão da matéria envolvendo os fatos da causa". Por conseguinte, a ausência de efeito suspensivo, preconizada nos arts. 637 do CPP e 27, $\S 2^{\circ}$, da Lei 8.038/90, faria sentido. Zavascki asseverou que a execução provisória da condenação penal, sujeita a recurso especial ou extraordinário, não compromete o núcleo essencial do princípio da presunção de inocência, tendo em vista que o acusado já teria sido tratado como se inocente fosse ao longo de todo o curso do "processo ordinário criminal", com a observância de direitos, garantias e regras probatórias.

Em suas palavras, Zavascki assinalou em seu voto que a execução da pena na pendência de recursos extraordinários "não compromete o núcleo essencial do pressuposto da não culpabilidade", pois o acusado foi tratado como inocente ao longo de todo o processo ordinário criminal, com o devido respeito às regras do devido processo legal. $\mathrm{O}$ voto condutor ainda trouxe crítica ao entendimento fixado em 2009, destacando que assegurar a presunção de inocência em grau absoluto tem estimulado a indevida (e sucessiva) interposição de recursos com evidentes propósitos protelatórios, frequentemente com o objetivo de levar à prescrição da pretensão estatal - já que o último marco interruptivo do prazo prescricional, antes do cumprimento da pena, é a publicação da sentença ou do acórdão condenatório recorrível ${ }^{32}$. Desse modo, defendeu que a retomada da jurisprudência tradicional -conferir somente efeito devolutivo aos recursos

\footnotetext{
${ }^{30}$ O Ministro Zavascki ressalva a via da revisão criminal, por meio da qual é possível obter a revisão dos fatos e das provas, nos termos do art. 621 e 626 do Código de Processo Penal. Este último prevê que: "Julgando procedente a revisão, o tribunal poderá alterar a classificação da infração, absolver o réu, modificar a pena ou anular o processo".

${ }^{31}$ Acrescentou o Relator que "Ao réu fica assegurado o direito de acesso, em liberdade, a esse juízo de segundo grau, respeitadas as prisões cautelares porventura decretadas.”.

${ }^{32}$ Necessário lembrar a incongruência criada pelo entendimento adotado no HC 84.078, já que não mais se podia executar provisoriamente a pena fixada no acórdão condenatória, mas o prazo prescricional iniciava a partir daí a sua contagem. No modelo proposto a partir do HC 84.078, não fazia mais sentido que se iniciasse a prescrição da pretensão executória no momento em que transitasse em julgado a sentença condenatória para a acusação, conforme redação do art. 112, I, do Código Penal, pois o réu somente seria preso após o trânsito em julgado da sentença penal acusatória para ambas as partes.
}

Revista de Direito Brasileira | São Paulo, SP | v. 16 | n. 7 | p. 186 - 210 | Jan./Abr. 2017 
excepcionais - é "mecanismo legítimo de harmonizar o princípio da presunção de inocência com o da efetividade da função jurisdicional do Estado". Por fim, advertiu sobre a possibilidade de ocorrerem equívocos nas condenações em instâncias ordinárias ${ }^{33}$, mas recordou a existência de instrumentos aptos a inibirem os danos a que se sujeitaria o condenado na hipótese de erro com a suspensão da execução provisória da pena, seja por meio de medidas cautelares para concessão de efeito suspensivo ao REsp ou ao RE, seja pela via do habeas corpus. Por esses motivos, Zavascki entendeu que o condenado não estaria desamparado em casos de manifesta violação de direitos.

O Ministro Edson Fachin iniciou o seu voto com uma tradução livre de uma frase de Robert H. Jackson, digna de reprodução: "não há dúvida de que, se houvesse uma Super Suprema Corte, uma porção substancial dos nossos julgados também seria reformada. Nós não temos a última palavra por sermos infalíveis. Somos infalíveis por termos a última palavra." 34 . O Ministro se utilizou de tal expressão para afirmar que, embora seja possível que as instâncias ordinárias incidam em erros na condenação de acusados, também estão sujeitas a equívocos as extraordinárias. Fachin ressaltou o papel do STJ e do STF, destacando que este último não configura uma Corte Constitucional nos moldes do sistema europeu continental, em razão das competências estabelecidas na Constituição. Nesse contexto, criticou a competência penal originária do Supremo - a qual considera injustificável exceção ao Princípio Republicano -, bem como o agigantamento dos afazeres do STF, que decorre da própria forma como esta Corte interpreta determinadas regras constitucionais ${ }^{35}$. Defendeu que, dentro da margem de conformação outorgada pela Constituição ao intérprete, sem extrapolar os limites da moldura textual, "as melhores alternativas hermenêuticas são as que conduzem a reservar à Corte a tutela da ordem jurídica constitucional" e não a inalcançável missão de fazer justiça aos casos concretos. Asseverou que "nenhuma norma, especialmente as de caráter principiológico, pode ser descontextualizada das demais normas constitucionais para adquirir foros de verdadeiros superprincípios", pois isso implicaria "ofuscar a eficácia de outras normas igualmente sediadas no topo da pirâmide normativa que é a Constituição".

Assim, na linha do voto do Relator, Fachin também interpretou o art. 5. ${ }^{\circ}$, LVII, da Constituição Federal, de modo a permitir a execução provisória da pena após condenação em segunda instância, por meio do que seria uma leitura da Constituição como um todo, ressaltando de forma específica a duração razoável do processo, a soberania dos veredictos do Tribunal do Júri, em relação aos crimes dolosos contra a vida, e, principalmente, o arcabouço recursal desenhado pela CF nos arts. 102 e 105. Fachin ainda observou que o STF e o STJ não foram concebidos para revisar as injustiças do caso concreto e defendeu que o revolvimento da matéria fática não deve estar ao alcance das Cortes Superiores, as quais podem apenas dar aos fatos afirmados nos acórdãos recorridos nova definição jurídica, não nova versão. Concluiu, então, que as instâncias ordinárias são soberanas na avaliação das provas e dos fatos. Extremamente perspicaz e merecedora de destaque a observação de Fachin no sentido de que viola frontalmente a soberania dos veredictos do Tribunal do Júri, que possui sede constitucional, a suspensão da eficácia de condenação por este órgão proferida até que sejam julgados todos os recursos proletórios interpostos pela defesa nas instâncias extraordinárias.

O Ministro Barroso, também acompanhando o Ministro Relator, fez três considerações principais. A primeira é de que a condenação de primeiro grau, mantida em segunda instância, inverte a presunção de inocência. A segunda é que o recurso extraordinário se destina apenas a discutir questões de direito, destacando que a materialidade e a autoria já teriam sido

\footnotetext{
${ }^{33}$ Alerta, porém, para o fato de que os erros também são cometidos nas instâncias extraordinárias.

${ }^{34}$ A frase original é a seguinte: "There is no doubt that if there were a super-Supreme Court, a substantial proportion of our reversals of state courts would also be reversed. We are not final because we are infallible, but we are infallible only because we are final".

${ }^{35} \mathrm{O}$ Ministro ressaltou que não faz apologia à chamada "jurisprudência defensiva".
}

Revista de Direito Brasileira | São Paulo, SP | v. 16 | n. 7 | p. 186 - 210 | Jan./Abr. 2017 
comprovadas com respeito ao duplo grau de jurisdição. A terceira, é que a impossibilidade de execução da pena após o segundo grau fomenta a interposição sucessiva de recursos protelatórios. Igualmente oportuno destacar a observação do Ministro Barroso no sentido de que a nova orientação adotada pelo Supremo restaura o prestígio e a autoridade das instâncias ordinárias. Barroso ainda enfatizou que a impossibilidade de execução provisória da pena, na pendência de recursos extraordinários, contribui para a seletividade do sistema punitivo brasileiro, uma vez que, na grande maioria das vezes, são os condenados com maior poder aquisitivo que conseguem exercer todas as possibilidades recursais existentes com vistas a protelar o trânsito em julgado e obter a prescrição intercorrente. ${ }^{36}$

Em resumo, o que se pode apontar como denominador comum entre os votos dos Ministros que acompanharam a proposta de retomada da orientação anterior é uma consternação em face do uso abusivo do direito de recorrer $^{37}$ e a necessidade de assegurar uma leitura sistemática dos efeitos atribuídos aos recursos de cariz extraordinário. Realçaram também a possibilidade de se conformar a literalidade do inciso LVII do art. 5. ${ }^{\circ}$ do texto constitucional com os demais preceitos constitucionais, de forma a permitir a execução provisória após a condenação em segundo grau. Por fim, mereceu destaque nesses votos o fato de que cabe às instâncias ordinárias o exame quanto aos fatos e provas, e, por conseguinte, quanto à autoria e materialidade do delito.

Entre os votos vencidos, merecem destaque as considerações lançadas pelo Ministro Celso de Mello, que buscou responder aos pontos indicados na orientação hoje prevalecente na Corte. Celso de Mello defendeu que a nova orientação configuraria uma "repulsa à presunção de inocência" e partiria de uma "visão incompatível com os padrões do regime democrático".

A propósito, não se trata de suprimir a proteção à presunção de inocência, mas de limitála à luz de outros interesses ou direitos igualmente tutelados em nosso ordenamento. Parece bastante ilógica a concepção de que a possibilidade de promover a execução provisória da pena representa uma repulsa à presunção de inocência e um retorno a uma presunção de culpabilidade, nos moldes propostos por Garófalo ou Manzini (citados por Celso de Mello). Já se delineou em tópico anterior que a compreensão do núcleo da presunção de inocência na forma defendida neste artigo é compatível com a execução provisória. Não é que se entenda que a tutela da presunção da inocência seja prescindível em um regime democrático, mas, sim, que o núcleo essencial do princípio - por não depender do trânsito em julgado - não obsta a execução provisória, como já consignado.

Em seu voto, Celso de Mello citou diversas declarações internacionais afirmando que tais normas consagrariam a "prerrogativa básica" de que "todos se presumem inocentes até que sobrevenha condenação penal transitada em julgado". Nesse ponto, contudo, vê-se um desvirtuamento do alcance dos referidos textos. Como já indicado, os diplomas internacionais asseguram a presunção de inocência, mas no limite da comprovação da culpa na forma da lei. $\mathrm{O}$ Ministro Celso de Mello trouxe em seu voto a análise de uma porcentagem ${ }^{38}$ (citando um voto anterior do Ministro Lewandowski) quanto à reforma de decisões criminais proferidas pelas instâncias ordinárias. Textualmente, afirmou Celso de Mello:

\footnotetext{
${ }^{36} \mathrm{O}$ Ministro Barroso destacou, nessa linha de raciocínio, que os infindáveis recursos protelatórios não são interpostos pelas pessoas que superlotam as prisões brasileiras.

${ }^{37}$ Quanto ao uso excessivo de recursos protelatórios, Vladimir Aras (2010) tece críticas ao sistema adotado no Brasil: "O processo tem de passar por todos os escaninhos imagináveis do Judiciário brasileiro. Em suma, os cidadãos temos de engolir toda essa sopa de letrinhas para ver os culpados serem finalmente punidos. Enquanto isso, o relógio prescricional segue no seu inabalável tic-tac, sacramentando um modelo de ARACC [trata-se de um trocadilho com uma classe processual no sistema de controle de autuações do STJ]".

${ }^{38}$ A referida porcentagem "caiu" no "inconsciente coletivo" e vem sendo repetida em diversos textos para criticar a decisão proferida pelo Supremo no HC 126.292 sem qualquer análise crítica de sua representatividade.
}

Revista de Direito Brasileira | São Paulo, SP | v. 16 | n. 7 | p. 186 - 210 | Jan./Abr. 2017 
Somando-se os parcialmente providos com os integralmente providos, teremos o significativo porcentual de $28,5 \%$ de recursos. Quer dizer, quase um terço das decisões criminais oriundas das instâncias inferiores foi total ou parcialmente reformado pelo Supremo Tribunal Federal nesse período.

Os dados indicados merecem consideração. Em primeiro lugar, cabe contrastar esse dado com uma pesquisa realizada pela Fundação Getúlio Vargas - FGV, segundo a qual a quantidade de reforma de decisões de segundo grau seria de 10\% (GOMES, 2016). Em segundo lugar, e mais importante, deve-se ter em mente que qualquer porcentagem de recursos providos (parcial ou totalmente) somente pode ser estabelecida sobre um universo de recursos conhecidos (número infinitamente menor, no âmbito das instâncias extraordinárias, do que a quantidade de recursos interpostos ${ }^{39} \mathrm{e}$, principalmente, do que as decisões prolatadas). Nesse cenário, não se pode dizer que, porque $28,5 \%$ de recursos foram providos, um terço das decisões de segundo grau foram reformadas pelo Supremo Tribunal Federal. Por fim, em contraponto à consideração feita pelo Ministro Celso de Mello $^{40}$, cumpre destacar que a execução provisória de acórdão penal condenatório proferido em grau de apelação em nada mitiga a regra probatória derivada da presunção de inocência, sendo exatamente este um dos motivos pelo qual se defende que a compatibilidade da execução provisória da pena com o modelo acusatório.

A decisão proferida pelo Plenário do STF, no julgamento do HC $126.292^{41}$, em 17 de fevereiro de 2016, promoveu melhoria no funcionamento do processo penal brasileiro e na operacionalidade do sistema penal, bem como rechaçou o uso indiscriminado e abusivo de recursos protelatórios com vistas a obter a prescrição. Com a orientação estabelecida em 2016, o processo penal permanece pautado num modelo acusatório de cariz garantista, em que se exige a concretização do devido processo legal e demais garantias constitucionais penais. Portanto, não há razões para que se tirem, na expressão de Eros Grau reproduzida por Bottini (2016), “os porretes do armário“.

Em outubro de 2016, o Pleno do STF reafirmou o entendimento de fevereiro, desta feita por ocasião da denegação da medida acauteladora pleiteada nas ações declaratórias de constitucionalidade n. 43 e n. 44, ajuizadas, respectivamente, pelo Partido Ecológico Nacional e pelo Conselho Federal da Ordem dos Advogados do Brasil. As ações de controle abstrato se dirigiam à afirmação de constitucionalidade do disposto no art. 283 do CPP, o qual, segundo sustentaram os autores, seria impeditivo da execução provisória da pena.

Em votação concluída em 5 de outubro de 2016, com argumentos que em grande medida reproduzem ou detalham aqueles já expendidos no julgamento de fevereiro, o STF reafirmou a compatibilidade da execução provisória da pena com a presunção da inocência. A diferença deuse, apenas, em relação ao voto proferido pelos Ministros Dias Toffoli e Rosa Weber. O primeiro propôs que a execução provisória da pena ocorresse apenas após o julgamento do recurso dirigido ao Superior Tribunal de Justiça; já a Ministra Rosa Weber, agora se debruçando detidamente sobre o assunto, visualizou a inviabilidade da execução provisória da pena com a literalidade da presunção de inocência tal como positivada na Constituição de 1988.

\footnotetext{
${ }^{39}$ A corroborar o alegado basta ver a movimentação dos Ministros do STJ e do STF para que fosse reestabelecido o juízo de admissibilidade no âmbito dos Tribunais Locais, o que provocou a edição da Lei 13.256/16 para alterar a Lei 13.105/15 (Novo CPC), antes mesmo de sua entrada em vigor.

${ }^{40}$ O Ministro Celso de Mello destacou que: "É por isso que o Supremo Tribunal Federal tem sempre advertido que as acusações penais não se presumem provadas, pois - como tem reconhecido a jurisprudência da Corte - o ônus da prova referente aos fatos constitutivos da imputação penal incumbe, exclusivamente, a quem acusa.".

${ }^{41}$ Após a decisão do Supremo, a Deputada Federal Keiko Ota apresentou o Projeto de Lei no 4774/2016, objetivando alterar o CPP para possibilitar a execução provisória de acórdão penal condenatório proferido em grau de apelação. Contudo, ao que sugere a leitura do referido PL, a Deputada não compreendeu a nova orientação da Corte, porquanto vinculou a prisão nesse momento aos requisitos do art. 312 do CPP.
}

Revista de Direito Brasileira | São Paulo, SP | v. 16 | n. 7 | p. 186 - 210 | Jan./Abr. 2017 
Espera-se, com a compreensão fixada em sede de controle abstrato de constitucionalidade, possa a Corte se debruçar a respeito de temas correlatos à execução provisória da pena, tais como a dimensão outorgada à definitividade da condenação como marco interruptivo da prescrição ${ }^{42}$ ou mesmo a possibilidade de gozo das benesses da execução penal na pendência da definitividade da condenação. ${ }^{43}$

\section{CONCLUSÕES}

A compreensão do sentido e do alcance de princípios se relaciona diretamente com o contexto histórico em que estão sendo interpretados, bem assim com o funcionamento do ordenamento jurídico em que se inserem.

Dentro de uma lógica sistemática, em que se busca um funcionamento operacional, pautar a interpretação de um princípio apenas na literalidade do texto em que prescrito reduz a efetividade do sistema como um todo e acaba por negar concretização a outros princípios igualmente importantes à ordem constitucional. No Brasil, a Constituição Federal propõe um Estado (Social) Democrático de Direito e o processo penal é orientado por um sistema acusatório. É indefensável a rejeição ao princípio da presunção de inocência em um Estado que se pretenda minimamente democrático e de Direito. A própria lógica do sistema acusatório se baseia na garantia de uma presunção de inocência do suspeito, investigado, indiciado, acusado ou réu.

Nos tratados internacionais de que o Brasil é signatário não há a exigência de que a inocência somente possa ser afastada por meio do trânsito em julgado da decisão que impôs o juízo de culpabilidade sobre o condenado. Em linhas gerais, o que se verifica é que o núcleo do Princípio da Presunção de Inocência se conecta com a necessidade de comprovação da culpa na forma da lei. Assim, o núcleo da presunção de inocência, garantia indispensável ao próprio Estado Democrático de Direito, não esbarra na necessidade do trânsito em julgado da decisão condenatória, mas tangencia o imperativo da comprovação da culpabilidade na forma da lei e o duplo grau de jurisdição.

A análise quanto à possibilidade ou não de se iniciar o cumprimento da pena após a condenação em segundo grau, no cenário jurídico brasileiro, exige, necessariamente, uma reflexão acerca do texto prescrito no art. 5, LVII, da Constituição Federal, a saber, "ninguém será considerado culpado até o trânsito em julgado de sentença penal condenatória". A Constituição Federal, embora adote em seu texto as expressões ora analisadas, não apresenta qualquer definição do que seja trânsito em julgado ou coisa julgada. O que se verifica é que a sentença penal condenatória não se reveste da qualidade de imutabilidade de forma absoluta.

A execução provisória da pena a partir da segunda instância não configura afronta à presunção de inocência, diante do espaço de conformação da norma positivada no art. $5^{\circ}$, LVII, da Constituição, bem como da compreensão sistemática do traçado normativo da ordem constitucional. Inviabilizar a execução da pena após a condenação em segundo grau rompe com a lógica do Sistema Acusatório. Aguardar o trânsito em julgado nas instâncias extraordinárias não se revela indispensável à preservação do núcleo da presunção de inocência.

Em um sistema acusatório, a responsabilidade penal de alguém só pode ser imposta por meio de um processo penal em que se limitou a pretensão punitiva do Estado e se garantiu a paridade de armas. Ao réu se deve assegurar o exercício do contraditório e da ampla defesa. À acusação incumbe demonstrar a culpa, afastado o uso de provas ilícitas. Consequentemente, a condenação só pode ser baseada em um juízo de certeza - já que a dúvida favorece o réu - e esse

\footnotetext{
${ }^{42}$ Tema em discussão à luz do disposto no art. 112, inc. I, do Código Penal, que teve repercussão geral reconhecida no ARE 848107 (Tema 788).

${ }^{43}$ Trata-se dos efeitos práticos da incidência do enunciado 716 da súmula do STF: "Admite-se a progressão de regime de cumprimento da pena ou a aplicação imediata de regime menos severo nela determinada, antes do trânsito em julgado da sentença condenatória”.
}

Revista de Direito Brasileira | São Paulo, SP | v. 16 | n. 7 | p. 186 - 210 | Jan./Abr. 2017 
julgamento só pode ser prolatado por um magistrado alheio, imparcial e independente, a quem se impõe o dever de fundamentação, com base no direito objetivo positivado na ordem jurídica. Portanto, a adoção de um modelo acusatório de processo penal, dentro do qual se inclui a garantia da presunção de inocência é compatível com a execução provisória da condenação, após o exercício do duplo grau de jurisdição. Muito mais que isso, é extremamente lógico que um juízo de condenação (duplamente) obtido, por meio de um processo assegurador de todas essas garantias, produza os seus devidos efeitos.

Até o ano de 2009, já sob a vigência da atual ordem constitucional, a jurisprudência do Supremo Tribunal Federal era no sentido da possibilidade da execução provisória da sentença penal condenatória confirmada em segunda instância, ainda que pendente o julgamento de recursos extraordinários, não detentores de efeito suspensivo. Em fevereiro de 2009, seguindo o posicionamento que vinha sendo adotado nas Turmas no tocante às penas restritivas de direitos, o Supremo, em decisão proferida de forma não unânime do Pleno no julgamento do HC 84.0787/MG, entendeu que a interpretação mais adequada a ser dada ao princípio da presunção de inocência vedava a possibilidade de se executar provisoriamente uma pena de prisão imposta em sentença condenatória não transitada em julgado.

Após sete anos, em fevereiro de 2016, no julgamento do HC 126.292/SP, de relatoria do Ministro Teori Zavascki, o Supremo restaurou a orientação tradicional da Corte no sentido de que: "a execução provisória de acórdão penal condenatório proferido em grau de apelação, ainda que sujeito a recurso especial ou extraordinário, não compromete o princípio constitucional da presunção de inocência". A decisão proferida pelo Plenário do STF, no julgamento do HC 126.292, em 17 de fevereiro de 2016, não violou o núcleo da presunção e inocência e pode promover uma melhoria no funcionamento do processo penal brasileiro, bem como rechaçar o uso indiscriminado e abusivo de recursos protelatórios com vistas a obter a prescrição. $\mathrm{O}$ entendimento de fevereiro foi reafirmado em outubro de 2016 por ocasião da negativa de medida cautelar pleiteada nos autos das ações declaratórios de constitucionalidade n. 43 e 44 pelo Pleno do STF.

\section{REFERÊNCIAS}

ARAS, Vladimir. Arre, égua! Que demora.... In: Blog do Vlad: temas de Justiça Criminal, Direitos Humanos, lavagem de dinheiro, crime organizado, cooperação internacional, segurança pública e o que mais valer a pena. 14 out. 2010. Disponível em: <https://blogdovladimir.wordpress.com/2010/10/14/arre-egua/>. Acesso em: 4 abr. 2016.

. Pelo MP - Equilíbrio de garantias. In: Jota: Justiça se escreve com Jota. 18 fev.

2016. Disponível em: <http://jota.uol.com.br/pelo-mp-equilibrio-de-garantias>. Acesso em: 4 abr. 2016.

ÁVILA, Humberto. Teoria dos princípios: da definição à aplicação dos princípios jurídicos. 14. ed. São Paulo: Malheiros, 2013. 216 p.

BARATTA, Alessandro. Criminologia Crítica e Crítica do Direito Penal: introdução à sociologia do direito penal. 6. ed. Rio de Janeiro: Revan, 2011. 256 p.

BARBAGALO, Fernando Brandini. Presunção de inocência e recursos criminais excepcionais: em busca da racionalidade no sistema processual penal brasileiro [recurso eletrônico] / Fernando Brandini Barbagalo. - Dados eletrônicos. - Brasília: TJDFT, 2015. 163 p. 
BATISTA, Nilo. Introdução Crítica ao Direito Penal Brasileiro. 12. ed. Rio de Janeiro: Revan, 2011. $136 \mathrm{p}$.

BECCARIA, Cesare. Dei delitti e delle pene. Milano: 1973. Disponível em: <http://www.letteraturaitaliana.net/pdf/Volume_7/t157.pdf >. Acesso em: 4 abr. 2016.

BEDAQUE, José Roberto dos Santos. Direito e Processo: influência do direito material sobre o processo. 5. ed. São Paulo: Malheiros, 2009. 192 p.

BITENCOURT, Cesar Roberto; BITENCOURT, Vania Barbosa Adorno. Em dia de terror, Supremo rasga a Constituição no julgamento de um HC. In: Coluna Reforma Constitucional. Conjur: Consultor Jurídico. 18 fev. 2016. Disponível em: <http://www.conjur.com.br/2016-fev18/cezar-bittencourt-dia-terror-stf-rasga-constituicao>. Acesso em: 4 abr. 2016.

BOTTINI, Pierpaolo Cruz. O retorno da execução provisória da pena: os porretes de Eros Grau. In: Coluna Direito de Defesa. Conjur: Consultor Jurídico. 23 fev. 2016. Disponível em: <http://www.conjur.com.br/2016-fev-23/direito-defesa-retorno-execucao-provisoria-penaporretes-eros-grau >. Acesso em: 4 abr. 2016.

BRASIL. Constituição da República Federativa do Brasil de 1988. Brasília, 5 de out. 1988. Disponível em: 〈http://www4.planalto.gov.br/legislacao>. Acesso em 2 jul. 2016.

. Decreto n. 678, de 06 de novembro de 1992. Convenção Americana sobre Direitos Humanos (Pacto de São José da Costa Rica). Promulgação. Diário Oficial da União, Brasília, 6 nov. 1992. Disponível em: <http://www4.planalto.gov.br/legislacao>. Acesso em 2 jul. 2016.

. Decreto-Lei n. 4.657, de 4 de setembro De 1942. Lei de Introdução às normas do Direito Brasileiro. Rio de Janeiro, 4 de set. 1942. Disponível em: <http://www4.planalto.gov.br/legislacao>. Acesso em 2 jul. 2016.

. Lei n. 8.038, de 28 de maio de 1990. Institui normas procedimentais para os processos que especifica, perante o Superior Tribunal de Justiça e o Supremo Tribunal Federal. Brasília, 28 mai. 1990. Disponível em: <http://www4.planalto.gov.br/legislacao>. Acesso em 2 jul. 2016.

Supremo Tribunal Federal. Canal STF no sítio YouTube, Pleno - Pena pode ser cumprida após decisão de segunda instância. Sessão de Julgamento do HC 126.292, em 17 de fev. 2016. Disponível em: <https://youtu.be/581ZjGsJmCA>. Acesso em: 4 abr. 2016.

Supremo Tribunal Federal. Ação Declaratória de Constitucionalidade n. 43. Medida Cautelar. Distrito Federal. Tribunal Pleno. Relator Ministro Marco Aurélio. Julgamento em 5 out. 2016. Pendente de publicação. Disponível em < http://www.stf.jus.br>. Acesso em 12 out. 2016.

Supremo Tribunal Federal. Ação Declaratória de Constitucionalidade n. 44. Medida Cautelar. Distrito Federal. Tribunal Pleno. Relator Ministro Marco Aurélio. Julgamento em 5 out. 2016. Pendente de publicação. Disponível em < http://www.stf.jus.br>. Acesso em 12 out. 2016. 
. Supremo Tribunal Federal. Habeas Corpus n. 84.078. Minas Gerais. Tribunal Pleno. Relator Ministro Eros Grau. Julgamento em 5 fev. 2009. DJ de 26 fev. 2010. Disponível em < http://www.stf.jus.br>. Acesso em 12 out. 2016.

Supremo Tribunal Federal. Tribunal Pleno. Habeas Corpus n. 126.292. São Paulo. Tribunal Pleno. Relator Ministro Teori Zavascki. Julgamento em 17 fev. 2016. DJ de 17 mai. 2016. Disponível em < http://www.stf.jus.br>. Acesso em 12 out. 2016.

BUSATO, Paulo César. O que não se disse sobre o STF, o HC 126.292 e a antecipação da execução de pena. Gen Jurídico. 1. ${ }^{\circ}$ mar. 2016. Disponível em: <http://genjuridico.com.br/2016/03/01/o-que-nao-se-disse-sobre-o-stf-o-hc-126-292-e-aantecipacao-da-execucao-de-pena/>. Acesso em: 4 abr. 2016.

CARVAlHO, Salo de. Antimanual de Criminologia. 5. ed. São Paulo: Saraiva, 2013. 452 p.

ESPANHA. Constitución Española, de 29 de diciembre de 1978. Disponível em: <http://www.boe.es/buscar/doc.php?id=BOE-A-1978-31229>. Acesso em: 15 abr. 2016.

FERRAJOLI, Luigi. Direito e Razão: teoria do garantismo penal. 2. ed. São Paulo: RT, 2006. $925 \mathrm{p}$.

FISCHER, Douglas. O que é garantismo penal (integral)?. In: Garantismo penal integral: questões penais e processuais, criminalidade moderna e a aplicação do modelo garantista no Brasil. orgs.: CALABRICH, Bruno. FISCHER, Douglas. PELELLA, Eduardo. 2. ed. Salvador: Juspodvium, 2013. 520 p.

FREITAS, Vladimir Passos de. Supremo restaura equilíbrio ao determinar execução provisória da pena. In: Coluna Segunda Leitura. Conjur: Consultor jurídico. 21 fev. 2016. Disponível em: <http://www.conjur.com.br/2016-fev-21/segunda-leitura-stf-restaura-equilibrio-determinarexecucao-provisoria-pena >. Acesso em: 4 abr. 2016.

FRISCHEISEN, Luiza Cristina Fonseca; GARCIA, Mônica Nicida; GUSMAN, Fábio. Execução provisória da pena: um contraponto à decisão do Supremo Tribunal Federal no Habeas Corpus n. 84.078. In: Garantismo penal integral: questões penais e processuais, criminalidade moderna e a aplicação do modelo garantista no Brasil. orgs.: CALABRICH, Bruno. FISCHER, Douglas. PELELLA, Eduardo. 2. ed. Salvador: Juspodvium, 2013. 520 p.

GADAMER, Hans-Georg. Verdade e Método. Vol. II. Complementos e Índice. Trad. Enio Paulo Giachini. Petrópolis: Ed. Vozes, 2002.

GOMES, Luiz Flávio. Como Compatibilizar a Prisão Cautelar com o Princípio Constitucional da Presunção da Inocência? In: Instituto Avante Brasil. 10 nov. 2011. Disponível em: <http://institutoavantebrasil.com.br/como-compatibilizar-a-prisao-cautelar-com-o-principioconstitucional-da-presuncao-da-inocencia/>. Acesso em: 4 abr. 2016.

. Execução provisória da condenação: tolerância zero com réus da lava jato? e os demais condenados no país? 19 fev. 2016. Disponível em: 
<http://luizflaviogomes.com/execucao-provisoria-da-condenacao-tolerancia-zero-com-reus-dalava-jato-e-os-demais-condenados-no-pais/\#_ftn1>. Acesso em: 4 abr. 2016.

HESSE, Konrad. Temas fundamentais do direito constitucional. São Paulo: Saraiva, 2009. 171 p.

INTER-AMERICAN COMMISSION ON HUMAN RIGHTS. Rapporteurship on the Rights of Persons Deprived of Liberty. Informe sobre el uso de la prisión preventiva en las Américas / [Preparado por la Relatoría sobre los Derechos de las Personas Privadas de Libertad de la Comisión Interamericana de Derechos Humanos]. Espanha: 2013. Disponível em: http://www.oas.org/es/cidh/ppl/informes/pdfs/informe-pp-2013-es.pdf. Acesso em: 4 abr. 2016.

JARDIM, Afrânio Silva. Garantismo no processo penal merece breve (e parcial) reflexão. In: Coluna Atuação do Estado. Conjur: Consultor jurídico. 8 jul. 2014. Disponível em: < http://www.conjur.com.br/2014-jul-08/afranio-jardim-garantismo-processo-penal-merecereflexao >. Acesso em: 4 abr. 2016.

KARAM, Maria Lúcia. Liberdade, Presunção de Inocência e Prisões Provisórias. Rio de Janeiro: Lumen Juris, 2009. 70 p.

LOPES JR., Aury. Direito processual penal. 10. ed. São Paulo: Saraiva, 2013. 1394p.

MENDES, Gilmar Ferreira. A presunção de não culpabilidade e a orientação do Ministro Marco Aurélio. In: Marco Aurélio Mello. (Org.). Marco Aurélio Mello: ciência e consciência. 1. ed.São Paulo: Migalhas, 2015, v. 1, p. 33-48.

MENDES, Gilmar Ferreira; COELHO, Inocêncio Mártires; BRANCO, Paulo Gustavo Gonet. Curso de direito constitucional. 2. ed. rev. e atual. São Paulo: Saraiva, 2008. 1432p.

OLIVEIRA, Eugênio Pacelli de. Curso de processo penal. 14. ed. Rio de Janeiro: Lumen Juris, 2011. 896 p.

Prefácio. In: Garantismo penal integral: questões penais e processuais, criminalidade moderna e a aplicação do modelo garantista no Brasil. orgs.: CALABRICH, Bruno. FISCHER, Douglas. PELELLA, Eduardo. 2 ed. Salvador: JusPodivm, 2013. 520 p.

NAÇÕES UNIDAS (UN). Assembleia Geral. Declaração Universal dos Direitos Humanos. 10 dez. 1948. Aprovada pela Resolução 217 A (III) da Assembleia Geral. Disponível em: <http://www.dudh.org.br/wp-content/uploads/2014/12/dudh.pdf >. Acesso em: 4 abr. 2016.

ORGANIZAÇÃO DOS ESTADOS AMERICANOS. Conjunto de Principios para la protección de todas las personas sometidas a cualquier forma de detención o prisión. Adoptado por la Asamblea General em su resolución 43/173, de 9 de deciembre de 1988. Disponível em: <https://www.cidh.oas.org/PRIVADAS/conjuntoprincipios.htm>. Acesso em: 4 abr. 2016.

Convenção Americana Sobre Direitos Humanos. Conferência Especializada Interamericana sobre Direitos Humanos, San José, Costa Rica, em 22 de novembro de 1969. 
Disponível em: <https://www.cidh.oas.org/basicos/portugues/c.Convencao_Americana.htm>. Acesso em: 4 abr. 2016.

Declaração Americana dos Direitos e Deveres do Homem. Aprovada na IX Conferência Internacional Americana, em Bogotá, em abril de 1948. Disponível em: <https://www.cidh.oas.org/basicos/portugues/b.Declaracao_Americana.htm>. Acesso em: 4 abr. 2016.

PORTUGAL. Constituição da República Portuguesa, de 25 de abril de 1976. Disponível em: $<$ http://www.parlamento.pt/Legislacao/Paginas/ConstituicaoRepublicaPortuguesa.aspx >. Acesso em: 15 abr. 2016.

PRADO, Geraldo. Sistema acusatório: a conformidade constitucional das leis processuais penais. 2. ed. Rio de Janeiro: Lumen Juris, 2001. 287 p.

ROXIN, Claus. Estudos de Direito Penal. Trad. Luís Greco, Rio de Janeiro: Renovar, 2006, $232 \mathrm{p}$.

SANTANA, Selma Pereira de. Uma crítica ao garantismo penal no Brasil: a hipossuficiência da proteção aos bens jurídicos supra-individuais. In: Temas de Direito Penal e Processual Penal: estudos em homenagem ao juiz Tourinho Neto. Salvador: JusPodivm, 2013. 751 p.

STRECK, Lenio Luiz; OLIVEIRA, Rafael Tomaz de. O que é isto - as garantias processuais penais? Porto Alegre: Livraria do Advogado, 2012. 114 p.

O dever de proteção do Estado (Schutzpflicht). Revista Jus Navigandi, Teresina, ano 13, n. 1840, 15 jul. 2008. Disponível em: 〈https://jus.com.br/artigos/11493>. Acesso em: 4 abr. 2016.

VIEIRA, Oscar Vilhena. Presunção de Inocência. Folha de São Paulo. 20 fev. 2016. Disponível em: <http://www1.folha.uol.com.br/colunas/oscarvilhenavieira/2016/02/1741320-presuncao-deinocencia.shtml $>$. Acesso em: 4 abr. 2016. 